Canonising the Shakespeare Apocrypha: Shakespeare, Middleton and Co-Existent Canons

\title{
Abstract
}

The Shakespeare Apocrypha has persisted as a category for plays of dubious authorship since 1908. Despite recent calls for this group to be dissolved, it persists as the "other" of the Shakespeare canon. The definition of the plays as a collectively excluded canon leads to their relative obscurity in print and on stage. Yet recent calls for the adoption of different kinds of dramatic canon present a means of reintegrating canon and apocrypha. The new Middleton Collected Works offers a model for "co-existent canons" which share plays and disperse the authority of fixed authorial canons, allowing the plays of the Shakespeare Apocrypha to be read and seen in new, productive contexts. 


\section{Canonising the Shakespeare Apocrypha: Shakespeare, Middleton and Co-Existent Canons}

In 2010, director Terry Hands produced a new production - his third - of the anonymous drama Arden of Faversham for Theatr Clwyd Cymru. The programme, white with the theatre's logo, boldly and simply stated "Arden of Faversham. By Anonymous" (title page). In 2011, a herald in Roland Emmerich's motion picture Anonymous repeated the latter words. As the elderly Queen Elizabeth (Vanessa Redgrave) is presented with a gift of a play, she asks who the writer may be. The Herald tentatively says "By Anonymous". Elizabeth pauses momentarily, puzzled, then leans back with a knowing smile. "Anonymous. I do so admire his verse".

In Emmerich's film, an anti-Stratfordian (or, as Paul Edmondson and Stanley Wells would now have us put it, "anti-Shakespearian", 32) historical fantasy that has been the occasion and focus of widespread discussion of Shakespearean authorship, "Anonymous" functions as a pseudonym for Edward de Vere, seventeenth Earl of Oxford. "Anonymous" has a distinct authorial voice and stands for the marked, pointed absence of a known author. In this, the word fits with Jeffrey Masten's suggestion, following Michel Foucault's quotation of Samuel Beckett, that anonymous "marks a space for identity, a need to know "who is speaking'" (12). Here, it is not the text that is anonymous, but the author who is Anonymous; the distinction is between the play that is claimed by an unknown and the play that is not claimed at all.

In the case of Hands's production of Arden of Faversham, "By Anonymous" serves a similar purpose. Since 1770, when Faversham resident Edward Jacob edited the play and claimed it for Shakespeare, Arden of Faversham has been part of the group of plays now most usually known as the "Shakespeare Apocrypha". Although this play, almost alone among the group of over seventy plays with similarly dubious ascriptions, has a rich editorial and performative history in its own right as an anonymous play, the Shakespeare ascription has remained a continual point of discussion. In 2006 and 2008, MacDonald P. Jackson reopened the argument that Shakespeare wrote at least the central quarrel scene of the play, and an edited version of this scene was subsequently included as an appendix on the website of the RSC Shakespeare. The arguments were supported by Hugh Craig and Arthur Kinney in 2009 but disputed by Brian Vickers in 2007 and 2010, and there is as yet no consensus on the play's author(s). It is in response to these claims that Hands's production makes a bold and deliberate assertion of anonymity for the play that, rather than omitting authorial attribution, creates a separate space for authorship that is explicitly other to Shakespeare, Kyd or any other named author. "Anonymous" here stands for a particular authorial identity, but this time a unique one, defined by its distinctive difference to the authors that it deliberately defies.

The plays of the Shakespeare Apocrypha sit at the heart of the semantic, cultural and literary debates over the ownership of a text by its author. Individually, many of the plays are not anonymous at all - some are explicitly by "William Shakespeare" (The London Prodigal, 1605), "W.S." (Thomas Lord Cromwell, 1601), "Mr. Theobald" (the avowedly 
revised Double Falsehood, 1728) and so on. Others are claimed by other authorities: "The Earle of Notingham Lord high Admirall of England his seruants" (1 Sir John Oldcastle, 1600) or "his Maiesties Seruants, at the Globe" (The Merry Devil of Edmonton, 1608). However, in the mid-seventeenth century collections of these plays that depended on their Shakespearean relationship began to circulate. Initially these collections asserted a positive authorial identification: the Pavier quartos of 1619 which included $A$ Yorkshire Tragedy and 1 Sir John Oldcastle, the hand-bound collection in the library of Charles I labelled "Shakespeare Vol. 1" which included seven disputed plays, ${ }^{1}$ the third Folio of 1664 which expanded the canon to forty-three plays for the next sixty years until their removal in the 1728 reissue of Alexander Pope's Complete Works. However, following Edmund Malone's 1780 edition of the disputed plays as a Supplement to the 1778 edition of Shakespeare's plays by George Steevens, nineteenth-century collections of the plays began titling them "Spurious" or "Doubtful Plays by/of William Shakespeare", as in the collections by Henry Tyrrell (1853?), Max Moltke (1869) and William Hazlitt (1887). Interestingly, the titles still make a positive connection - regardless of their spuriousness or doubtfulness, they remain "plays of Shakespeare" (my emphasis). The authorial signifier maintains the explicit and implicit connection between man and plays, albeit with the qualifier that casts the relationship in an uncomfortable light. The wording also suggests that it is the plays themselves that are doubtful rather than the authorial connection; yet again, there is a slippage of terminology that blurs the boundaries of canon.

The title The Shakespeare Apocrypha was first used in 1908 by Charles Frederick Tucker Brooke, in his edition of fourteen disputed plays for the Clarendon Press. Here, the possessive is altered - the plays are no longer "of" Shakespeare, but instead a new canonical category is established which groups them and links them to an idea of Shakespeare, as the Biblical Apocrypha are other to, but not of, the Bible. By creating the Apocrypha, and consolidating the canon of doubtful plays, however, Brooke complicates matters even further. "Of the forty-two 'doubtful plays' just enumerated, only thirteen can be regarded as having acquired a real claim to the title [of Apocrypha]" (xi). Plays are required to have "established their position in the category", and "each writer on the subject must decide for himself which may be admitted into the 'doubtfully Shakespearian' class without offence to the rules of critical seemliness" (vii). The irony of having a "real" claim to "doubtful" status bypasses Brooke entirely, as does his oxymoronic implication that some plays are more authentically dubious than others. The arbitrariness of definition here points to the problem that continues to vex studies of the Shakespeare Apocrypha - how, in a study dominated by authorial canons, can we accommodate a grouping of plays with such porous boundaries, whose constituent plays both belong and do not belong to the Author?

\section{New Approaches}

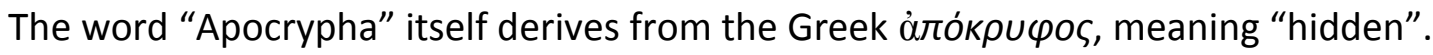
Yet despite the endurance of Brooke's title for the group into the twenty-first century, the 
plays themselves have never been less hidden. Since 2005, new critical editions of Sir Thomas More (Arden Shakespeare, 2011), Edward III (Oxford Shakespeare, 2005) and Double Falsehood (Arden Shakespeare, 2010) have been added to leading Shakespeare series, and the Royal Shakespeare Company has staged all three since the turn of the century. ${ }^{2}$ In 2010 alone it was possible to see productions of Arden of Faversham, $A$ Yorkshire Tragedy and Double Falsehood in London. Further, the resurgence of authorship studies, including the foundation of the London Forum for Authorship Studies in 2005 (the first regular seminar devoted to the methodology of attribution work), has seen a plethora of new work on plays of disputed authorship including by Brian Vickers (Arden of Faversham, Fair Em, Edward III), Hugh Craig and Arthur Kinney (Arden, Edmond Ironside, The Spanish Tragedy), Ward Elliott and Robert J. Valenza (Edward III, Thomas More), MacDonald Jackson (Arden) and others. The plays have even been reappropriated recently for the cause of authorship conspiracy theories, with writers such as Sabrina Feldman arguing that the Apocrypha were genuinely written by William Shakespeare of Stratford-upon-Avon, while the canonical plays were the work of Thomas Sackville, and John Raithel and John Casson arguing that they reveal the authorship of William Stanley and Henry Neville respectively. The orthodox scholar will scoff, but the fascination that the plays hold reminds us that the division between Canon and Apocrypha is neither as absolute as their varied treatments suggest, nor is dissolved enough to allow us to simply ignore the value judgements that have blighted the plays.

While the canon has always been in a state of steady flux as plays such as Pericles, The Two Noble Kinsmen, Titus Andronicus and Thomas More have moved in and out of favour, we are now in a period of increased canonical mobility. A combination of historicist scholarship interested in the wider cultural contexts of plays, and post-structuralist approaches to texts and authorship, has renewed interest in theatrical repertories and early modern book culture, prioritising the discursive, social contexts in which plays and playbooks circulated. In this kind of environment, absolute distinctions between bodies of work organised by author become misleading, imposing prior limitations on our study that fail to represent the historical realities of playmaking. Studies such as those of Roslyn Knutson and Andrew Gurr insist on the interrelatedness of Shakespeare's plays with others in the same repertory, presenting us with a series of theatrical relationships that predate the Canon/Apocrypha division. The revitalisation of attribution studies, with a particular focus on collaboration across the early modern drama and especially within the Shakespeare canon, has further challenged the primacy of the individual author. An "Apocrypha" has inescapably Biblical connotations in that it subsists as the inverse of the Authorised Canon; but when that Authority is itself dispersed, an Apocrypha ceases to carry its meaning.

Despite the immediate importance of the question, there have been surprisingly few attempts to address explicitly the existence of the category, which is usually referred to in passing as a critical shorthand, as in Laurie Maguire's mention of "[t]he apocryphal work The London Prodigal" (15), or else dismissed as dated with no attempt to confront the 
implications of that shift. The fact is that despite movements to move away from authordominated models of looking at early modern drama, the apocryphal plays remain ostracised in critical attention and are still dominated by the question of attribution. Partly this is due to the relative lack of good editions and performances of the plays, with scholars being dependent instead on amateur productions and facsimile editions. Partly, however, it remains the case that all scholars speaking of "Shakespeare" must begin with a sense of what that consists of, and in doing so the distinction between Canon and Apocrypha is immediately assumed.

Three short and under-read studies have explicitly addressed the question of the existence of an Apocrypha in recent years, and it is to these that this essay responds. Christa Jansohn, in The Shakespeare Apocrypha: A Reconsideration, argues that "the lack in willingness to include any more plays in the canon encourages the selective recollection of certain plays of the Elizabethan times" (324), and she picks up on

the implicit division into good and bad apocrypha [that] indicates a phenomenon that is characteristic of the traditional canon as well as of the works combined outside of the canon in subcanons. (324)

For Jansohn, the idea of an Apocrypha has become particularly acute in literature, where an in/out binary mentality has been preserved by the increasing use of quantitative methodologies of authorship, as opposed to the visual arts where a range of scales of authenticity (hand-created by artist, created by studio and so forth) encourages the interpretational questions that the Shakespeare Apocrypha are rarely subjected to. It is a canon, as Jansohn puts it, which preserves variety apart from in the critical assumption that they are all "inferior" to Shakespeare. Yet the maintenance of this canon as inferior itself promotes a form of selective reading.

Jansohn's call for renewed attention to the apocryphal plays unfettered by authorbased value judgements is still to be met, and the framework within which these discussions take place is often itself the focus of attention. Brean Hammond's 2010 edition of Double Falsehood treats judiciously the historical, literary, political and theatrical contexts in which the 1727 play came into being, but it was the appearance of a title page with the banner heading "The Arden Shakespeare" that dominated discussion boards and newspaper headlines. ${ }^{3}$ The paradox remains that in order for the Apocrypha to lose their stigmatised status, they need to be given appropriate critical and editorial treatment, but the authorbased canons into which early modern drama is currently organised (even open-ended series such as the Arden Early Modern Drama and the Revels Plays are defined by their nonShakespearean status) require a prior decision to be made about the authorial claims of the piece. The plays remain defined by their otherness in relation to Shakespeare, and the distinction between Shakespeare and non-Shakespeare is maintained.

Two essays by Richard Proudfoot ("Is There, and Should There Be, a Shakespeare Apocrypha?") and John Jowett ("Shakespeare Supplemented") have, however, proposed strategies for breaking down the dichotomy between Canon and Apocrypha. Proudfoot, described by Jansohn as "The Nestor of Apocrypha studies" (329), argues that Brooke's 
fourteen-play Apocrypha should be reduced to six by dismissing plays based on their date (The Birth of Merlin), company (Sir John Oldcastle) or internal evidence (A Yorkshire Tragedy, The Puritan). With these plays dismissed, he takes the remainder (London Prodigal, Locrine, Thomas Lord Cromwell, Mucedorus, Merry Devil, Fair Em) and suggests renaming the group "Shakespeare's unattributed repertoire" (65). To these, he suggests, might we add the other anonymous plays associated with companies to which Shakespeare may have belonged, such as A Warning for Fair Women, The Fair Maid of Bristow and The True Tragedy of Richard III (65-6). Proudfoot's aim is to consolidate authorial canons as far as possible and then create a more open, fluid space between them, where prior assumption about authorship are removed in favour of a less stigmatised group.

There are two difficulties with this approach. The first is that it retains the Apocrypha in all but name, continuing to consolidate authorial canons as a priority and thus still separates anonymous and attributed plays in ways that preserve the division. To separate the "unattributed repertoire" from the attributed is still to impose an anachronistic division on early modern plays. The second is that it discounts the weight of critical history bearing on the plays. The relocation of $A$ Yorkshire Tragedy to the Middleton canon, for example, does not solve the play's interesting problems: it cannot erase four hundred years of association with Shakespeare, or explain the unambiguous attribution on that play's title page.

Jowett's article "Shakespeare Supplemented" is more concerned with the editorial history of the Apocrypha, and the formation of the apocryphal canon during the eighteenth and nineteenth centuries. Like Proudfoot, he looks forward towards the dissolution of the Canon/Apocrypha dichotomy, although notes

this is not to say that the era of the supplement can be declared to be over; it is still with us, with all the uncertainty it ever had as to whether it has meaningful existence, the ambiguity in defining terms such as "doubtful" and "attributed," and the unconformity of its constituent parts. (66)

Instead, he offers the suggestion that

The dichotomy of "canon" and "Apocrypha" can be replaced with a gradualist model of Shakespeare's works that recognises that even the play of purest Shakespeare authorship is susceptible to minor modifications on the part of that familiar procession of actors, playbook annotators, scribes, stationers, and compositors. (66)

Jowett's "gradualist model" offers a wider reaching approach that deconstructs ideas of a pure Shakespeare and thus places all drama on a continuum. The difficulty here, however, is that it lacks the definition needed for the publishing and compilation of drama, at least in print form. In theoretical and in practical terms, if a canon is entirely open-ended and we accept the possible presence of a revising or editing Shakespeare in any number of minor plays, how can we continue to speak of a "Complete Works" of Shakespeare? The risk is that we accept the possibility of minor collaboration, but continue to work within essentialist ideals of authorship that maintain the received canon to the continued exclusion of unattributed drama. The other option is to adopt a system which partitions plays and sections of plays into separate authorial canons, as in the excerpting of the "Hand D" 
sections of The Book of Sir Thomas More into Shakespeare editions without their theatrical context. This is the practice E.K. Chambers dismissed as "disintegration" and which threatens to re-emerge as what Brian Vickers calls "restitution":

If scholars analyse plays in which readers have long noticed major discrepancies with Shakespeare's language and dramaturgy ... they are not 'disintegrating' Shakespeare's solely authored text but reclaiming the appropriate parts for their original authors. This is a work of elementary justice, to begin with ... Such a study should properly be called not 'disintegration' but 'restitution.' (Shakespeare, Co-Author 137-38)

However Vickers draws the distinction, the problem remains that the approach ideologically strips discrete sections of collaborative plays from the setting which gives them meaning, and "restores" them to a single-authored context, denying what Masten, at the other extreme, sees as the very meaning of collaborative theatre: "The collaborative project in the theatre was predicated on erasing the perception of any differences that might have existed, for whatever reason, between collaborated parts" (17). Certainly it seems that any approach which treats collaborative or disputed plays by separating them out will always be a blunt tool for negotiating the complexities and varieties of dramatic collaboration.

\section{The Shakespeare/Middleton Canon}

A productive approach might be found, however, in other recent attempts at canonisation, specifically the new Thomas Middleton: Collected Works edited by Gary Taylor and John Lavagnino and published by Oxford University Press. This is an unusual volume, that simultaneously canonises the author in a massive volume dominated by a single authorial name, but also disperses auctorial authority throughout. The presence of collaborators is obvious throughout the edition, and there is even a full edited "work" which contains no contribution by Middleton at all: Aleksei Ziuzin's eyewitness account of a performance of The Triumphs of Truth (977-79), a pageant to which Middleton contributed. Middleton is a theme, or meme, within his own collected volume, a point of shared contact for a discursive culture rather than a dominating authorial figure.

Among the many striking features of the edition is the choice to include plays that are already undisputedly attached to established authorial canons. The volume not only includes A Yorkshire Tragedy, The Puritan and The Lady's Tragedy (better known as The Second Maiden's Tragedy), which have all been part of the Shakespeare Apocrypha, ${ }^{4}$ but also claims Macbeth, Measure for Measure and Timon of Athens as collaborations with or revisions of Shakespeare by Middleton.

Vickers's assault in the Times Literary Supplement on the decision to include Macbeth in the edition challenged the findings of Taylor and Lavagnino's team, presenting alternative statistical tests that argued for Shakespeare's sole authorship of the play. He asserts that "A Middletonizing process has begun" ('Disintegrated') with Taylor's introduction of the words "incipit actus primus" at the play's opening, a changing of the play to accommodate it to the Middleton volume. While the rights or wrongs of both positions are beyond the scope of this article to evaluate, the rhetoric of Vickers's argument is pertinent:

Considering that Shakespeare is universally admired, and the most frequently performed dramatist, one of the few whose (estimated) birthday is regularly celebrated around the 
globe, we might expect that the texts of his plays would be protected, like some World Heritage site. But no, editors of varying ability, and publishers of varying prestige, regard them as malleable material, to be cut or expanded as they wish. ('Disintegrated')

Later, expressing concern over Taylor's general editorship of the new Oxford Shakespeare, he adds "[w]e can only wonder what damage the helpless text will suffer from his next exercise of editorial power".

The boundaries of the authorial canon are, to pursue Vickers's reasoning, designed as protective barriers, given to preserving and containing the authorised canon. It is difficult to see how Taylor's practice differs from the "restitution" practiced by Vickers throughout Shakespeare, Co-Author which redistributes sections of Pericles, Titus Andronicus, Timon of Athens, The Two Noble Kinsmen and Henry VIII to other writers, and in fact it is a difference in methodology and results that separates Taylor and Vickers rather than a difference in respect for the text (although Taylor is the only one of the two to pursue his results into editorial practice). Vickers's colourful imagery imagines that this World Heritage Site has been in some way violated, as if Taylor's treatment of Macbeth is akin to the con-artist Victor Lustig's attempt to sell the Eiffel Tower for relocation to the USA.

A text is not a monument, however, and the boundaries of canon are far more porous than is here acknowledged. Jowett points out that " $[t]$ he presentation of the boundaried Folio and the unregulated aspirants to Shakespearian authoriality belong alike to the field of book production" ('Supplemented' 65); the impression of canons as bound separately and apart from one another is an effect of the book form that doesn't represent the circulation of plays as collaborative and intersecting. The Oxford Middleton does not seek to take Macbeth, Measure for Measure and Timon of Athens away from Shakespeare, and indeed the edition credits Shakespeare consistently for these plays. Jowett, introducing the edition's treatment of Macbeth, states:

[T] he intention is not to dispute the fact that the greater part of this play, by far, was written by William Shakespeare ... Macbeth is presented here, then, as part of both the Shakespeare and the Middleton canon, to be read and seen if not at the intersection of the two canons at least at a point where one touches the other rather more than tangentially. ('Macbeth' 1165)

The Oxford Middleton - which is itself based on the two-volume format of the Oxford Shakespeare, utilising Shakespeare's cultural prestige in order to elevate Middleton's by the same standard - is offering an insight into how a principle of co-existing canons may work. In Taylor's rather ostentatious description, "We do not have to choose between them ... We are simply blessed, enriched, by their coexistence, their wrestling with each other and the world" (58).

Of the six plays in the Middleton/Shakespeare/dubitanda sub-canon that I have listed, Macbeth, Measure for Measure and Timon have a fixed place in the Shakespeare canon. A Yorkshire Tragedy and The Puritan are available in Brooke's Shakespeare Apocrypha, and $A$ Yorkshire Tragedy is also included in the non-author-specific Revels Plays series. The Lady's Tragedy is widely available: attributed to Shakespeare and Fletcher as Cardenio in Charles Hamilton's notorious 1994 edition, but more respectably as The 
Maiden's Tragedy in Martin Wiggins's Four Jacobean Sex Tragedies. None of the plays belongs solely to Middleton in print circulation, but are shared by several different organising principles that draw attention to different aspects.

The "problem" of the Shakespeare Apocrypha is the unavailability of its constituent parts owing to its very definition as an excluded body of plays. The in/out binary of the Canon and Apocrypha imposes a clear value distinction, which has resulted in the plays not being re-edited as a group since 1908 , despite their shared historical connection to Shakespeare. ${ }^{5}$ While individual plays have appeared in other formats, as noted above, this only serves to point up the canonical dislocation of these itinerant wanderers, retaining the Apocrypha as the only firm body of work to which they undisputedly "belong".

The dislocation of undisputed plays from the Shakespeare canon to the Middleton, however, acts as a polemic to assert the fluidity of all authorial canons. If even a safe play such as Macbeth can be shared between two canons, then any play can. This returns to arguments advanced by Proudfoot for the adoption of multiple paradigms of authorship:

I also wish to question the reluctance of publishers and readers to contemplate other criteria than the sometimes slippery one of authorship for constructing collections of plays, criteria which might reflect other, equally significant, common characteristics of the plays. Such collections might include the plays associated with particular acting companies, or with particular playhouses, or with particular moments in theatrical history; they would also allow for proper attention to plays of doubtful or unknown authorship. ( 'Canon' 70) One of the advantages of the Middleton/Shakespeare shared canon as offered by the Oxford Middleton is its identification of a period of sustained engagement between the two writers within the repertory of the King's Men, encompassing Timon of Athens (written collaboratively by Shakespeare and Middleton c.1604), A Yorkshire Tragedy (written by Middleton c.1605, published as by Shakespeare in 1608) and The Lady's Tragedy (written by Middleton c.1611, later attributed speculatively to Shakespeare); in addition to Middleton's authorship of The Revenger's Tragedy for the company (c.1606) and his later revision of two of Shakespeare's plays of this period, Measure for Measure (c.1603) and Macbeth (c.1605). Attention to the interconnectedness of plays written for a specific playing company may draw out useful links: for example, the acceptance of damnation shared by the protagonists of Othello, A Yorkshire Tragedy and The Revenger's Tragedy, eschewing repentance for what A.C. Cawley describes as a "Christian tragedy" of eternal as well as mortal death ("A Yorkshire Tragedy" 117). Macbeth and The Witch stand, for the first time, in the same volume, allowing for comparison of the two plays that even Vickers accepts contain at least two shared songs and therefore share a performative connection that transcends simple authorial distinctions.

The notion of co-existent canons recasts the canon itself not as a boundaried home for plays, but rather as a totem around which plays cluster. The textual, theatrical and authorial provenances of various groups of plays are all brought into play in the body of a single edition, allowing for an opening-up rather than shutting-down of the intertextual connections between works. This is implicit in the very title of a Collected Works - for completeness, in a discursive culture, ceases to be a useful aspirational goal. 
To return to where I began, the apocryphal play which provides the best precedent for the fortunes of the co-owned play remains Arden of Faversham. As well as in the Shakespeare Apocrypha and collections of dubitanda, Arden can be found in stand-alone editions in the Revels Plays and New Mermaids series, and collected in the volumes Plays on Women and A Woman Killed with Kindness and Other Domestic Plays. A scene is excerpted on the website of the RSC Shakespeare, and the full play will be included in Jonathan Bate and Eric Rasmussen's forthcoming Collaborative Plays by Shakespeare and Others. In the same year that it was performed in isolation at Theatr Clwyd, it was also revived at the Rose Theatre on Bankside as part of that theatre's ongoing programme of rare Elizabethan revivals (also including 1 Henry VI, Soliman and Perseda, Titus Andronicus and The Spanish Tragedy), authorised by a performance space and a specific historical period. It is the privilege of the truly anonymous play to move freely between canons that pick up on aspects of its putative authorship, its historical moment, its theatrical provenance, and its thematic concerns. Paradoxically, this play's dislocation also allows it an interpretive freedom that is denied to those plays more firmly bound to an authorial canon; the only plays routinely denied a space in collections ordered by genre, company, theme, plot or period are Shakespeare's, confined to the canon that imprisons them even as it preserves. ${ }^{6}$

Proudfoot's argument is that "the time has come both to narrow and intensify the study of Shakespeare 'Apocrypha', and to widen our sense of the valid meanings of a Shakespeare 'canon'” ('Canon' 93). The embracement of multiple, intersecting canons utilising a range of organising principles such as date, repertory, genre or playhouse offers a way to achieve this, paying greater attention to the social contexts that created the plays while not ignoring the issues of authorship that have dominated study of the plays so far. If the Oxford Middleton does not offer a paradigmatic shift in terms of our conceptions of authorship, retaining as it does the monolithic author in a bound volume, it does at least offer one model for the co-existent canon that integrates the material, performative and collaborative contexts of plays within the authorial model and shares plays with other major canons. An Apocrypha only exists as the unauthorised counterpart to a fixed canon; if the Shakespeare canon itself begins to be dispersed among these intersecting canons, then the plays of the Apocrypha may begin finally to be defined not by what they fail to be, but by what they are.

\section{Works Cited}

Anonymous. Dir. Roland Emmerich. Perf. Rafe Spall, Vanessa Redgrave, Rhys Ifans. Sony, 2011. Film.

Bate, Jonathan, and Eric Rasmussen, eds. Collaborative Plays by Shakespeare and Others. Basingstoke: Macmillan, forthcoming.

Brooke, C.F. Tucker, ed. The Shakespeare Apocrypha: Being a Collection of Fourteen Plays 
Which Have Been Ascribed to Shakespeare. Oxford: Clarendon Press, 1908.

Casson, John. Enter Pursued by a Bear: The Unknown Plays of Shakespeare-Neville. Bognor Regis: Music for Strings, 2009.

Casson, John. Much Ado about Noting: Henry Neville and Shakespeare's Secret Source. London: Dolman Scott, 2010.

Cawley, A.C., and Barry Gaines, eds. A Yorkshire Tragedy. Manchester: Manchester UP, 1986. The Revels Plays.

Chambers, E.K. 'The Disintegration of Shakespeare.' 1924. Aspects of Shakespeare: Being British Academy Lectures. Oxford: Oxford UP, 1933. 23-48.

Clwyd Theatr Cymru. Arden of Faversham. Theatre Programme. Clwyd: 2010. Print.

Craig, Hugh, and Arthur F. Kinney, eds. Shakespeare, Computers, and the Mystery of Authorship. Cambridge and New York: Cambridge UP, 2009.

Edmondson, Paul, and Stanley Wells. Shakespeare Bites Back: Not So Anonymous. Stratfordupon-Avon: Shakespeare Birthplace Trust, 2011. Web.

Elliott,Ward E.Y., and Robert J. Valenza. 'Two Tough Nuts To Crack: Did Shakespeare Write the 'Shakespeare' Portions of Sir Thomas More and Edward III?' Rev. version. Literary and Linguistic Computing 25.1 (2010): 67-83; 25.2 (2010): 165-77.

Feldman, Sabrina. The Apocryphal William Shakespeare. Indianapolis: Dog Ear Publishing, 2011.

The first part of the true and honorable historie, of the life of Sir John Old-castle, the good Lord Cobham As it hath been lately acted by the right honorable the Earle of Notingham Lord high Admirall of England, his seruants. London, 1600. Early English Books Online. Web. 25 July 2011.

Gurr, Andrew. The Shakespeare Company 1594-1642. Cambridge: Cambridge UP, 2004. Print.

Hamilton, Charles, ed. Cardenio; Or, The Second Maiden's Tragedy. Lakewood: Glenbridge, 1994.

Hammond, Brean, ed. Double Falsehood. London: Arden Shakespeare, 2010.

Hazlitt, William, ed. The Doubtful Plays of William Shakspeare. London, 1887. 
Jackson, MacDonald P. 'Shakespeare and the Quarrel Scene in Arden of Faversham.' Shakespeare Quarterly 57.3 (2006): 249-93.

Jackson, MacD. P. 'New Research on the Dramatic Canon of Thomas Kyd.' Research Opportunities in Medieval and Renaissance Drama 47 (2008): 107-27.

Jansohn, Christa. 'The Shakespeare Apocrypha: A Reconsideration.' English Studies 84 (2003): 318-29.

Jowett, John. 'Shakespeare Supplemented.' The Shakespeare Apocrypha. Ed. Douglas A. Brooks. Lampeter: Edwin Mellen Press, 2007. 39-73.

Jowett, John, ed. 'The Tragedy of Macbeth: A Genetic Text.' Taylor and Lavagnino 11651201.

Jowett, John, ed. Sir Thomas More. London: Arden Shakespeare, 2011.

Knutson, Roslyn L. The Repertory of Shakespeare's Company, 1594-1613. Fayetteville: U of Arkansas P, 1991.

Kozlenko,William, ed. Disputed Plays of William Shakespeare. New York: Hawthorn Books, 1974.

The London prodigall As it was plaide by the Kings Maiesties seruants. By VVilliam Shakespeare. London, 1605. Early English Books Online. Web. 25 July 2011.

Maguire, Laurie. 'Introduction.' Textual Formations and Reformations. Eds. Laurie E. Maguire and Thomas L. Berger. Newark: U of Delaware P, 1998. 11-18.

Malone, Edmond, ed. Supplement to the edition of Shakspeare's plays published in 1778 by Samuel Johnson and George Steevens. In two volumes. Containing additional observations ... to which are subjoined the genuine poems of the same author, and seven plays that have been ascribed to him; with notes by the editor and others. 2 vols. London, 1780. Eighteenth Century Collections Online. Web. 25 July 2011.

Masten, Jeffrey. Textual Intercourse: Collaboration, Authorship, and Sexualities in Renaissance Drama. Cambridge: Cambridge UP, 1997.

McLuskie, Kathleen E., and David Bevington, eds. Plays on Women. Manchester: Manchester UP, 1999.

Melchiori, Giorgio, ed. King Edward III. Cambridge and New York: Cambridge UP, 1998.

The merry deuill of Edmonton. As it hath beene sundry times acted, by his Maiesties Seruants, at the Globe, on the banke-side. London, 1608. Early English Books Online. Web. 
25 July 2011.

Moltke, Max, ed. The Doubtful Plays of William Shakespeare. Leipzig, 1869.

Proudfoot, Richard. 'Canon.' Shakespeare: Text, Stage and Canon. London: The Arden Shakespeare, 2001. 61-96.

Proudfoot, Richard. 'Is There, and Should There Be, a Shakespeare Apocrypha?' In The Footsteps of William Shakespeare. Ed. Christa Jansohn. Münster: Lit, 2005. 49-71. Studien zur englischen Literatur 20.

Raithel, John. The URL of Derby.Web. 29 November 2011.

The RSC Shakespeare. Macmillan, 2008. Web. 25 July 2011.

Taylor, Gary. 'Thomas Middleton: Lives and Afterlives.' Taylor and Lavagnino 25-58.

Taylor, Gary, and John Lavagnino, eds. Thomas Middleton: The CollectedWorks. Oxford: Clarendon Press, 2007.

Theobald, Lewis. Double falshood; or, the distrest lovers. A play, as it is acted at the TheatreRoyal in Drury-Lane. Written originally by W. Shakespeare; and now revised and adapted to the stage by Mr. Theobald, the Author of Shakespeare Restor'd. London, 1728. Eighteenth Century Collections Online. Web. 25 July 2011.

The true chronicle historie of the whole life and death of Thomas Lord Cromwell As it hath beene sundry times publikely acted by the Kings Maiesties Seruants. Written by VV.S. London, 1613. Early English Books Online. Web. 4 August 2011.

Tyrrell, Henry, ed. The Doubtful Plays of William Shakspere; Being all the Dramas attributed to the Muse of the World's Great Poet. London, 1853[?]. Open Library. Web. 25 July 2011.

Vickers, Brian. Shakespeare, Co-Author: A Historical Study of Five Collaborative Plays. Oxford and New York: Oxford UP, 2002.

Vickers, Brian. 'Thomas Kyd, Secret Sharer.' Times Literary Supplement. Times Literary Supplement, 18 April 2008.

Vickers, Brian. 'Disintegrated: Did Thomas Middleton Really Adapt Macbeth?' Times Literary Supplement. Times Literary Supplement, 28 May 2010.Web. 25 July 2011.

Vickers, Brian. 'The Canon of Thomas Kyd.' London Forum for Authorship Studies. School of Advanced Study, University of London. 18 July 2010. Web.

White, Martin, ed. Arden of Faversham. 1982. 2nd ed. New Mermaids. London: A \& C Black, 2007. 
Wiggins, Martin, ed. Four Jacobean Sex Tragedies. Oxford: Oxford UP, 1998.

Wiggins, Martin, ed. AWoman Killed with Kindness and Other Domestic Plays. Oxford: Oxford UP, 2008.

\footnotetext{
${ }^{1}$ For discussion of this collection, see Kirwan, Peter. 'The First Collected "Shakespeare Apocrypha"'. Shakespeare Quarterly 62:4 (2011).

${ }^{2}$ An adapted version of Double Falsehood was performed as Cardenio: Shakespeare's 'Lost Play' Re-imagined in Gregory Doran's 2011 production.

${ }^{3}$ The best summary of the controversy is that of Hammond himself in a forthcoming essay 'After Arden.' The Quest for Shakespeare's Cardenio. Eds. David Carnegie and Gary Taylor. Oxford: Oxford UP, forthcoming.

${ }^{4}$ While single editions such as that of Charles Hamilton have advanced the play's Shakespeare connection, The Lady's/Second Maiden's Tragedy has never been included in a collected edition of Shakespearean dubitanda, making it unique among plays with a seventeenth century attribution to Shakespeare.

${ }^{5}$ The 1974 edition by William Kozlenko only offers a reprint of Henry Tyrrell's 1853 edition. ${ }^{6}$ For a rare and exciting exception, see Emma Smith's forthcoming Five Revenge Tragedies, which includes the 1603 text of Hamlet alongside plays by Kyd, Marston, Chettle and Middleton.
} 